\title{
CCAAT/Enhancer Binding Protein Beta
}

National Cancer Institute

\section{Source}

National Cancer Institute. CCAAT/Enhancer Binding Protein Beta. NCI Thesaurus. Code C104118.

CCAAT/enhancer-binding protein beta ( $345 \mathrm{aa}, \sim 36 \mathrm{kDa}$ ) is encoded by the human CEBPB gene. This protein plays a role in the regulation of acute-phase reaction, inflammation and hemopoiesis. 